\title{
Removal of Diclosulam Pesticide Residues in Water samples using Cu Doped ZnO Nanocatalyst
}

\author{
Varada Nageswara Rao ${ }^{1}$, N. V. S. Venu Gopal ${ }^{2 *}$ and T. B. Patrudu ${ }^{3}$ \\ ${ }^{1}$ Department of Chemistry, Acharya Nagarjuna University, Guntur, Andhra Pradesh, India \\ ${ }^{2}$ Department of Chemistry, Institute of Science, GITAM University, Visakhapatnam, India \\ ${ }^{3}$ Department of Chemistry, School of Science, GITAM University, Hyderabad campus, \\ Telangana, India \\ *Corresponding author
}

\section{A B S T R A C T}

\begin{tabular}{|l|}
\hline Key w or d s \\
Cu-Zn NPs, \\
Diclosulam, \\
XRD, SEM, \\
HPLC-UV, DT50 \\
\hline Article Info \\
\hline $\begin{array}{l}\text { Accepted: } \\
10 \text { October } 2020 \\
\text { Available Online: } \\
10 \text { November } 2020\end{array}$ \\
\hline
\end{tabular}

\section{Introduction}

Diclosulam is an organic compound commercially available as a herbicide, with the chemical formula $\mathrm{C}_{13} \mathrm{H}_{10} \mathrm{C}_{12} \mathrm{FN}_{5} \mathrm{O}_{3} \mathrm{~S}$. Diclosulam is a sulphonamide soil applied herbicide which controls broad-leaved weeds in peanuts, soybean and other crops. It is taken up by roots and foliage and inhibits the acetolactate synthesis [1]. It is used in noncropland areas and for brush control. By entering the plant through the root zone and
Copper dopped Zinc Oxide nanoparticles (NPs) were prepared as a photocatalyst by using a precipitation method for the removal of diclosulam pesticide in water. The experiment was performed under direct sunlight at a single fortification level $(1 \mu \mathrm{g} / \mathrm{ml})$ at different $\mathrm{pH}$ levels $(\mathrm{pH} 4.0,7.0$ and 9.0). The optimum catalyst concentration recommended for complete degradation was found as $100 \mathrm{mg} / \mathrm{L}$ under sunlight. Diclosulam residues in water were determined by HPLC- UV detector and the rate constant and DT50 values were calculated from the obtained data. Based on the results we observed that $\mathrm{Cu}-\mathrm{Zn}$ NPs acted as excellent photocatalyst for the decontaminating of the diclosulam pesticide residues in water samples. 
number of crops, such as citrus fruit and pineapple [6-8]. In order to ensure food safety, many nations, such as America, Canada, and Japan, have set the maximum residue limit (MRL) of diclosulam in foods as low as 0.03 ppm [9, 10]. Diclosulam is also found to be excellent in controlling perennial grasses. It is therefore necessary to establish sensitive methods for determining the concentration of diclosulam.

Photocatalysis is a term that dates back almost 100 years and could simply be defined as a change in the rate of chemical transformation under the action of light in the presence of a catalyst that absorbs light and is involved in a chemical reaction. Although examples of heterogeneous photocatalysis spanning this period can be found, a significant growth period in the field of photocatalysis took place in the 1970s.

The use of $\mathrm{Cu}-\mathrm{ZnO}$ NPs as photocatalyst in visible light has already been reported to be effective in the photo degradation of various organic complexes. In this study, we have studied the effectiveness of $\mathrm{Cu}-\mathrm{ZnO}$ NPs, which have been synthesized by a reaction of copper nitrate and zinc nitrate, for photo degradation of diclosulam in water under visible light.

Residues are quantified using a highperformance liquid chromatography UV method (HPLC-UV) to understand the $\mathrm{pH}$ effect with different $\mathrm{pH}$ water samples (4.0, 7.0 and 9.0). The optimum catalyst concentration required for complete residue decontamination has also been determined by varying the amount of the catalyst from 1 to $200 \mathrm{mg} / \mathrm{L}$. The catalytic activity was measured at single concentration levels of the test item under direct sunlight.

X-Ray Diffraction (XRD), Scanning Electron Microscope (SEM), Transmission Electron Microscope (TEM) and Fourier Transform
Infra-Red (FTIR) spectroscopy have characterized the synthesized $\mathrm{Cu}-\mathrm{ZnO}$ NPs.

\section{Materials and Methods}

Reference analytical standard of diclosulam (purity $99 \%$ ), Zinc nitrate and Coppernitrate were obtained from Sigma Aldrich. The test item diclosulam 84\% WDG was purchased from the local market. Acetonitrile, HPLC grade Water, Sodium hydroxide LR grade, Potassium chloride GR grade, Boric acid GR grade, Potassium biphthalate GR grade, Hydrochloric acid AR grade and Potassium phosphate AR grade were obtained from the Merck India limited. Distilled water was purified by using the Milli-Q Plus apparatus (Millipore, Bedford, MA, USA).

\section{Preparation of $\mathrm{Cu}$ Doped $\mathrm{ZnO}$ nanoparticles}

Pure and $\mathrm{Cu}$ doped $\mathrm{ZnO}$ nanoparticles were synthesized by the Sol-gel process. 0.2 M aqueous ethanol solution of Zinc Nitrate was prepared under constant magnetic stirring of Zinc Nitrate for one hour. After complete dissolution of Zinc Nitrate, 0.1 M Copper Nitrate aqueous solution was added to Zinc Nitrate solution under high-speed constant stirring, drop by drop (slowly for $15 \mathrm{~min}$ ) touching the walls of the vessel and adjusted to $\mathrm{pH}$ at 9 using $1.0 \mathrm{M} \mathrm{NaOH}$. The mixed solution results in the formation of light blue precipitate and the stirring process again continued for 2 hours. The beaker sealed at this condition and allowed to settle overnight. The supernatant solution obtained separated carefully.

The remaining solution was centrifuged for 10 min and the precipitate obtained was centrifuged till no solvent remains. Thus, precipitated $\mathrm{Cu}-\mathrm{ZnO}$ nanoparticles were cleaned repeatedly with deionized water to remove unwanted impurities bound with nanoparticles. The washed precipitate then 
dried in an oven at about $60^{\circ} \mathrm{C}$. During drying $\mathrm{Cu}-\mathrm{Zn}(\mathrm{OH})_{2}$ is completely converted into $\mathrm{Cu}$ doped $\mathrm{ZnO}$.

\section{Standard stock solution}

The reference standard stock solution was prepared by weighing accurately $10.25 \mathrm{mg}$ of known purity diclosulam into a $10 \mathrm{ml}$ volumetric flask using an analytical balance of $0.01 \mathrm{mg}$ accuracy. The content of each flask was dissolved and makeup to the mark using HPLC grade acetonitrile.

\section{Sample stock solution}

Accurately $23.67 \mathrm{mg}$ of test item (purity $84.5 \%$ ) of diclosulam was taken into a $20 \mathrm{~mL}$ volumetric flask. The content was dissolved, sonicated and makeup to the acetonitrile mark in $5 \mathrm{~mL}$ of acetonitrile. Consequently, the final concentration was $1000 \mathrm{mg} / \mathrm{L}$. The stock sample solution was used for the preparation of dose samples in different aqueous solutions.

\section{Acidic Buffer}

The buffer solution of $\mathrm{pH} 4.0$ was prepared by dissolving $4.0 \mathrm{~g}$ of disodium hydrogen orthophosphate in $1.0 \mathrm{~L}$ milli-Q water and the $\mathrm{pH}$ was adjusted to $4.0 \mathrm{using} 1.0 \mathrm{~mole} / \mathrm{L}$ hydrochloric acid solution.

\section{Neutral Buffer}

The buffer solution of $\mathrm{pH} 7.0$ was prepared by dissolving $4.0 \mathrm{~g}$ of potassium dihydrogen orthophosphate in 1.0 L milli-Q water and the $\mathrm{pH}$ was adjusted to 7.0 using $1.0 \mathrm{~mol} / \mathrm{L}$ sodium hydroxide solution.

\section{Basic Buffer}

The buffer solution of $\mathrm{pH} 9.0$ was prepared by dissolving $1.25 \mathrm{~g}$ of boric acid and in $1.0 \mathrm{~L}$
milli-Q, water and the $\mathrm{pH}$ were adjusted to 7.0 using $1.0 \mathrm{~mol} / \mathrm{L}$ sodium hydroxide solution.

\section{Adsorption study of the catalyst}

Recovery studies in water and different $\mathrm{pH}$ waters were conducted with $100 \mathrm{mg} \mathrm{L}^{-1}$ level of catalyst and reported \% of recoveries in distilled water and different $\mathrm{pH}$ water.

\section{Method validation}

Validation of the method ensures the credibility of the analysis. The accuracy, precision, linearity and detection limit (LOD) and quantification (LOQ) parameters were considered in this study [11].Recovery tests were used, samples spiked at concentration levels of 0.03 and $0.3 \mu \mathrm{g} / \mathrm{mL}$ to determine the accuracy. Different known concentrations $(0.03,0.1,0.5,1.0,2.0$ and $5.0 \mu \mathrm{g} / \mathrm{mL})$ that were prepared by diluting the stock solution were used to determine linearity. The detection limit (LOD, $\mu \mathrm{g} / \mathrm{mL}$ ) was identified as the lowest concentration resulting in a 3fold response to the baseline noise defined by the control sample analysis. The limit of quantification (LOQ, $\mu \mathrm{g} / \mathrm{mL}$ ) was established as the lowest concentration ration of a diclosulam with a 10 -fold response to the baseline noise [12-13].

\section{Photolytic and photocatalytic studies}

Photolytic and photocatalytic studies were carried out in a borosil glass bottle under sunlight at GITAM University, Visakhapatnam. Each one liter of milli-Q water, $\mathrm{pH} 4.0,7.0$ and 9.0 buffer solution were doped with $1 \mathrm{~mL}$ of $1000 \mathrm{mg} / \mathrm{L}$ stock solution of pesticide formulation to get $1 \mu \mathrm{g} / \mathrm{mL}$ of active pesticide concentration. We prepared 2 sets, one set was used for photolytic study and another set used for the photo catalytic study. Before exposure to the 
sunlight, the resultant suspension was sonicated in the dark for 10 min to get an even dispersion of $\mathrm{Cu}-\mathrm{ZnO}$ NPs and attain adsorption equilibrium. Then the samples were exposed to direct sunlight. Aliquots of samples were collected on pre-determined intervals. The temperature of water samples during the period was 26 to $38^{\circ} \mathrm{C}$. The samples collected on different sampling occasions were filtered using $0.2 \mu \mathrm{m}$ PTFE membrane filter and collected the filtrates into amber-colored vials.

All the samples were stored in dark at $\angle 5^{\circ} \mathrm{C}$ before subjecting to HPLC-UV analysis. The samples fortified with Zn NPs particles were centrifuged using Beckman cooling centrifuge at $4000 \mathrm{rpm}$ for 5 minutes at $5^{\circ} \mathrm{C}$. Transferred the supernet into the amber-colored bottles and stored in dark at $<5^{\circ} \mathrm{C}$ until analysis to avoid further degradation of residues.

\section{Sampling}

Test samples were collected from the bottle at different depth on different time intervals after exposure to sunlight $(0,5,10,24$ and 48 hours for the photo catalytic experiment). The collected samples were centrifuged and filtered through $0.2 \mu$ filter and analyzed in HPLC.

\section{Chromatographic separation}

The HPLC-UV system consisting of Shimadzu high-performance liquid chromatograph equipped with a reversedphase Column Zorbex C8 $(15 \mathrm{~cm}$ length $\mathrm{x}$ $0.46 \mathrm{~cm}$ id $\mathrm{x} 3.5 \mu \mathrm{m}$ ) was used in this study. The temperature of the oven was kept at $30^{\circ} \mathrm{C}$.

The volume of the sample injected was $10 \mu \mathrm{L}$. Acetonitrile and HPLC water were mobile phases A and B [60:40 (v / v)]. The flow rate with a detector wavelength of $220 \mathrm{~nm}$ was kept at $1.0 \mathrm{~mL} / \mathrm{min}$. For this analysis, the external standard calibration method was used.

\section{Results and Discussion}

\section{XRD Analysis}

Figure 1 represents the XRD spectra of pure and $\mathrm{Cu}$ doped $\mathrm{ZnO}$ nanoparticles synthesized using the sol-gel process. In figure 1 diffraction peaks appear at $12.78^{\circ}, 16.78^{\circ}$, $29.29^{\circ}, 31.38^{\circ}, 35.40^{\circ}, 36.40^{\circ}, 38.86^{\circ}, 39.27^{\circ}$ and $45.25^{\circ}$ respectively. Diffraction peaks keenly indexed as hexagonal wurtzite structure of $\mathrm{ZnO}$. No change in the crystalline structure was detected due to $\mathrm{Cu}$ doping which suggests the majority of $\mathrm{Cu}$ atoms were in the $\mathrm{ZnO}$ wurtzite lattice. The average crystalline size and lattice strain calculated from the most intense peak of XRD spectra are found to be $23.8 \mathrm{~nm}$ and 0.0055 in the case of pure $\mathrm{ZnO}$ and $20.28 \mathrm{~nm}$ and 0.0071 $\mathrm{nm}$ in the case of $\mathrm{Cu}$-doped $\mathrm{ZnO}$ nanopowders. From spectra, it is also clear that nanopowders of doped and undoped $\mathrm{ZnO}$ possess high crystallinity and purity. This shows that $\mathrm{Cu}^{2+}$ ion successfully occupies the lattice size rather than the interstitial one. This is because the ionic radius of $\mathrm{Cu}^{2+}(0.73 \AA)$ is very close to that of $\mathrm{Zn}^{2+}(0.74 \AA)$, due to which $\mathrm{Cu}$ can easily penetrate the $\mathrm{ZnO}$ crystal lattice. From XRD data it was clear that the incorporation of $\mathrm{Cu}$ into $\mathrm{ZnO}$ lattice decreases the crystalline size, which further improves the structural properties of nanopowders.

\section{SEM analysis}

The scanning electron microscopy (SEM) images of pure and $\mathrm{Cu}$ doped $\mathrm{ZnO}$ is shown in figure 2. The SEM micrograph indicates that, with increasing $\mathrm{Cu}$ concentration, the shape and morphology of $\mathrm{ZnO}$ nanoparticles change. The image revealed that the individual particles were composed of the 
collection of particles of various shapes with increasing $\mathrm{Cu}$ concentration. This indicates that the morphology of $\mathrm{ZnO}$ nanoparticles is strongly affected by $\mathrm{Cu}$ ion doping. These images also show that with increasing $\mathrm{Cu}$ concentration and dispersivity, the agglomeration in nanoparticles increases, the homogeneity of particles was not good.

\section{FTIR analysis}

Figure 3 represents the FTIR spectra of pure and $\mathrm{Cu}$ doped nanoparticles recorded in the range of $400-4000 \mathrm{~cm}^{-1}$. The position and number of absorption bands depend not only on the structure of the crystal, the chemical composition, but also the morphology of the crystal. Fundamental modes of vibration observed around $3400 \mathrm{~cm}^{-1}$ corresponds to $\mathrm{OH}$ vibrations. Peaks observed around 1600 $\mathrm{cm}^{-1}$ corresponds to O-H-O vibrations. Significant modes of vibration of $1300 \mathrm{~cm}-1$ correspond to $\mathrm{C}-\mathrm{H}$ stretching vibrations. It is very important to identify that $\mathrm{Cu}$ doping affects the spectra In Figure 3 the $\mathrm{Zn}-\mathrm{O}$ band is observed at $455 \mathrm{~cm}^{-1}$ and Figure 4 below $700 \mathrm{~cm}-1$ many peaks are observed attached to $\mathrm{Zn}-\mathrm{O}$ which assigned as a $\mathrm{Cu}-\mathrm{O}$ stretching mode. This is due to the presence of $\mathrm{Cu}$ ion in the doped sample. A small hump observed at 2043.09 attributed to the presence of carbon dioxide. Various shifts observed in the spectra might be due to the $\mathrm{Cu}$ incorporation.

\section{TEM Analysis}

Figure 4 shows the TEM image of $\mathrm{ZrO} 2$ NPs. The figure indicates that $\mathrm{Cu}-\mathrm{ZnO}$ NPs were uniform and cylindrical. The average particle size calculated was about $50 \mathrm{~nm}$ using ImageJ software.

\section{Specificity}

Specificity was confirmed by injecting the Mobile phase solvents i.e., Acetonitrile and HPLC water, sample solution standard solution and buffer controls (acidic, neutral, basic). The chromatograms did not have matrix peaks to interfere with the diclosulam residue analysis shown in Fig. 5, 6 and 7. Furthermore, the retention time of diclosulam was constant at $3.2 \pm 0.4 \mathrm{~min}$.

Table.1 Calibration details of diclosulam

\begin{tabular}{|l|l|}
\hline Concentration in $(\mathbf{m g} / \mathbf{L})$ & Peak area of diclosulam $(\mathbf{m A U})$ \\
\hline 5 & 85247 \\
\hline 2 & 33985 \\
\hline 1 & 17025 \\
\hline 0.5 & 8564 \\
\hline .1 & 1652 \\
\hline 0.03 & 368 \\
\hline
\end{tabular}

Table.2 Statistical Parameters details diclosulam at $0.1 \mathrm{mg} / \mathrm{L}$ fortification level

\begin{tabular}{|l|l|}
\hline $\begin{array}{l}\text { Statistical Parameters } \\
\text { (6 Replications) }\end{array}$ & Results \\
\hline \% of men Recovery & 87.23 \\
\hline SD & 1.61 \\
\hline \% RSD & 1.48 \\
\hline Horwitz Limit Value & 1.52 \\
\hline
\end{tabular}


Table.3 Dissipation data for Photolytic decontamination of diclosulam in water under direct sunlight

\begin{tabular}{|c|c|c|c|}
\hline \multicolumn{4}{|c|}{ Diclosulam } \\
\hline \multirow{2}{*}{$\begin{array}{c}\text { Occasion } \\
\text { (Days) }\end{array}$} & \multicolumn{3}{|c|}{ Residues $(\boldsymbol{\mu g} / \mathbf{m L})$} \\
\hline $\mathbf{p H} 4.0$ & $\mathbf{p H ~ 7 . 0}$ & $\mathbf{p H ~ 9 . 0}$ \\
\hline $\mathbf{5}$ & 0.998 & 0.996 & 0.993 \\
\hline $\mathbf{1 0}$ & 0.789 & 0.745 & 0.601 \\
\hline $\mathbf{1 5}$ & 0.694 & 0.45 & 0.396 \\
\hline $\mathbf{2 0}$ & 0.521 & 0.314 & 0.215 \\
\hline $\mathbf{5 0}$ & 0.412 & 0.189 & 0.109 \\
\hline $\mathbf{1 0 0}$ & BDL & BDL & BDL \\
\hline
\end{tabular}

Table.4 Dissipation data for photo catalytic decontamination of diclosulam in water under direct sunlight

\begin{tabular}{|l|l|l|l|}
\hline \multicolumn{4}{|c|}{ Diclosulam } \\
\hline \multirow{2}{*}{$\begin{array}{l}\text { Occasion } \\
\text { (hours) }\end{array}$} & \multicolumn{2}{|c|}{ Residues $(\boldsymbol{\mu g} / \mathbf{m L})$} \\
\hline $\mathbf{0 H} 4.0$ & pH 7.0 & pH 9.0 \\
\hline $\mathbf{6}$ & 0.985 & 0.981 & 0.975 \\
\hline $\mathbf{1 2}$ & 0.625 & 0.589 & 0.702 \\
\hline $\mathbf{1 8}$ & 0.362 & 0.326 & 0.389 \\
\hline $\mathbf{2 4}$ & 0.178 & 0.121 & 0.102 \\
\hline $\mathbf{4 8}$ & 0.087 & 0.084 & 0.053 \\
\hline & BDL & BDL & BDL \\
\hline
\end{tabular}

Table.5 Kinetic parameters for Photolytic decontamination of diclosulam in water under direct sunlight

\begin{tabular}{|l|l|l|l|}
\hline Kinetic parameters & Water & \\
\cline { 2 - 4 } & pH 4.0 & pH 7.0 & pH 9.0 \\
\hline Diclosulam & \multicolumn{3}{|l|}{} \\
\hline DT $_{50}$ (Days) & 28.87 & 15.70 & 6.36 \\
\hline $\mathrm{k}$ & -0.010 & -0.019 & -0.047 \\
\hline
\end{tabular}

Table.6 Kinetic parameters for photocatalytic decontamination of diclosulam in water under direct sunlight

\begin{tabular}{|l|l|l|l|}
\hline \multirow{2}{*}{ Kinetic parameters } & Water & \multicolumn{2}{|l|}{} \\
\cline { 2 - 3 } & pH 4.0 & pH 7.0 & pH 9.0 \\
\hline Diclosulam & \multicolumn{3}{|l|}{} \\
\hline DT $_{50}$ (hours) & 6.81 & 6.40 & 5.36 \\
\hline $\mathrm{k}$ & -0.044 & -0.047 & -0.056 \\
\hline
\end{tabular}


Fig.1 XRD spectra of copper doped $\mathrm{ZnO}$ nanoparticles

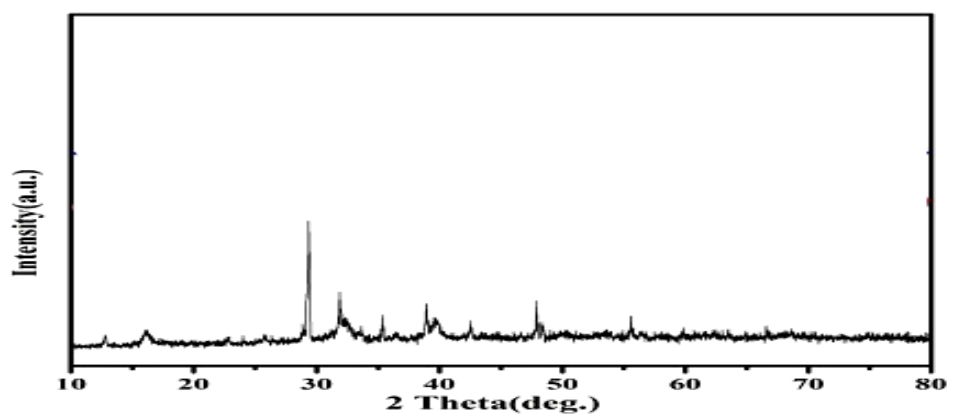

Fig.2 SEM spectra of $\mathrm{Cu}$ doped ZnO NPs

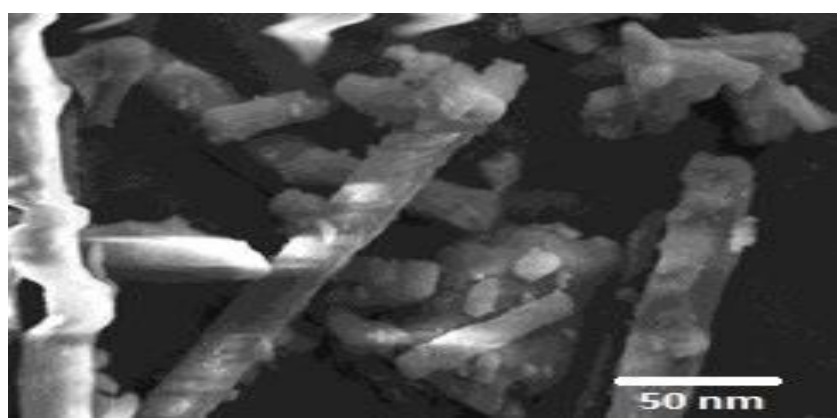

Fig.3 FTIR spectra of $\mathrm{Cu}$ doped ZnO Nanoparticles

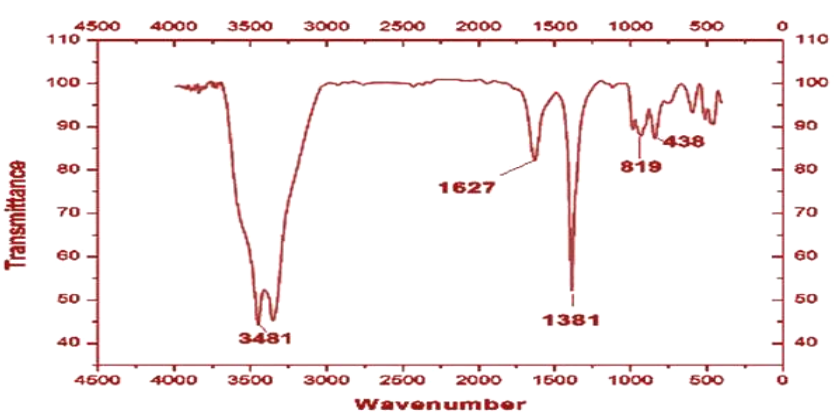

Fig.4

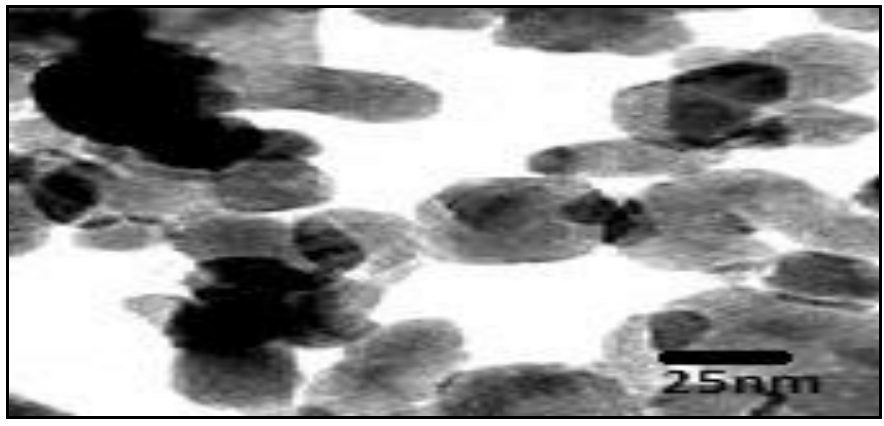


Fig.5 Representative chromatogram of diclosulam test item in acidic water- $12^{\text {th }}$ hour

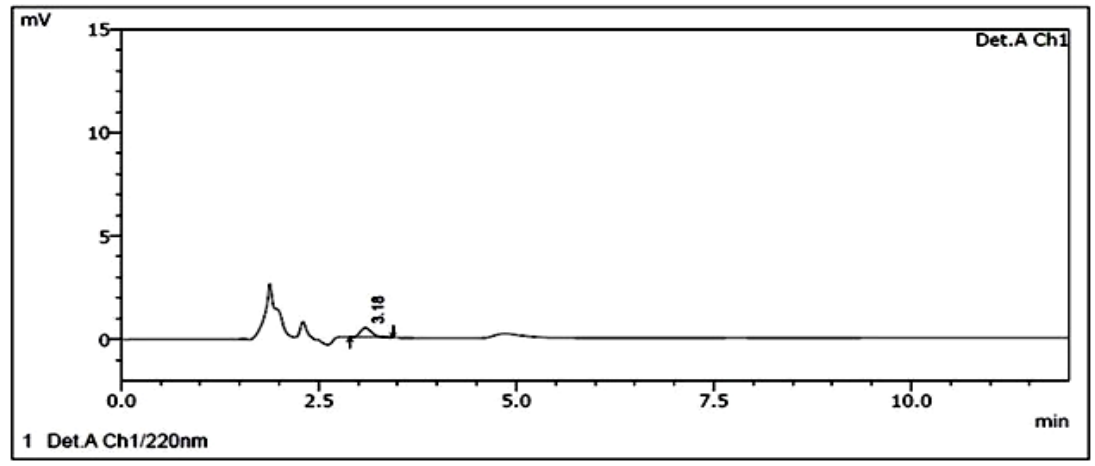

Fig.6 Representative chromatogram of diclosulam test item in neutral water $-12^{\text {th }}$ hour



Fig.7 Representative chromatogram of diclosulam test item in basic water $-12^{\text {th }}$ hour



Fig.8 Representative Calibration curve of diclosulam standard

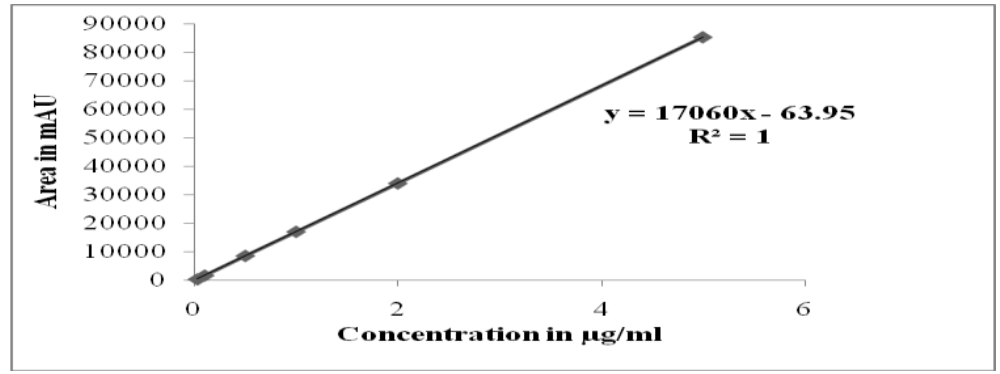


Fig.9 Graph representing the dissipation curve of photolytic decontamination of diclosulam in water under direct sunlight

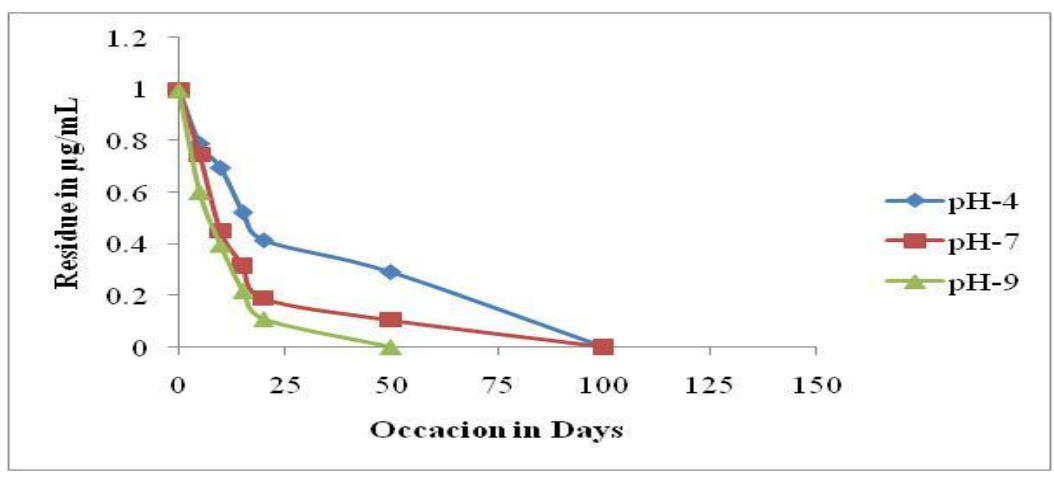

Fig.10 Graph representing the dissipation curve of photo catalytic decontamination of diclosulam in water under direct sunlight

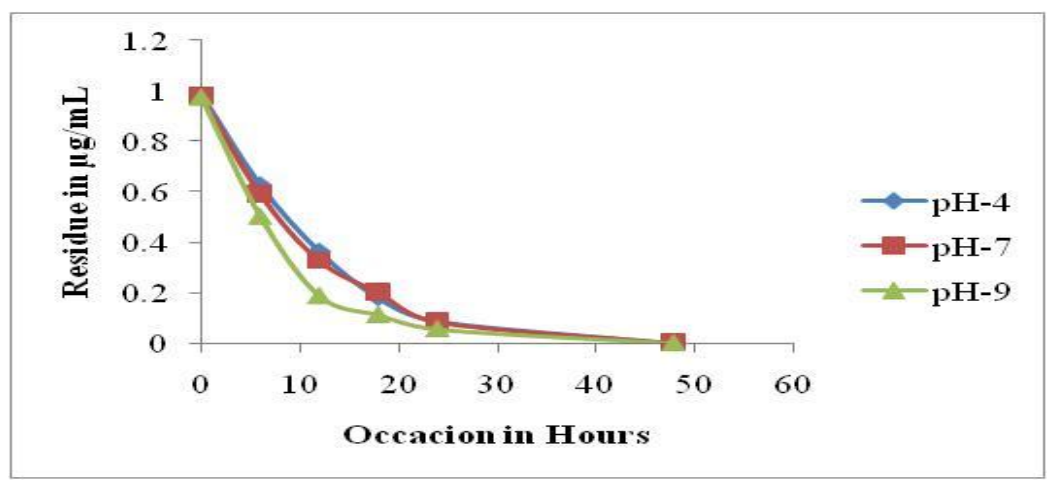

\section{Linearity}

Different known concentrations of diclosulam $(0.03,0.1,0.5,1.0,2.0$ and $5.0 \mu \mathrm{g} / \mathrm{mL})$ were prepared into a different $10 \mathrm{~mL}$ volumetric flasks by diluting the stock solution. These standard solutions were directly injected into an HPLC. An analysis of six standard concentration solutions evaluated a calibration curve has plotted for the concentration of the standards injected versus area observed and the linearity of the method. The details were presented in Table 1. To calculate the linear regression equation, the peak areas obtained from various concentrations of standards were used. This was $\mathrm{Y}=15060 \mathrm{X}+64.90$ with correlation coefficient of 0.9998 respectively. A calibration curve is shown in Fig. 8.

\section{Recovery}

The method had an acceptable recovery range $(80-110 \%)$ for pesticide in four different glasses of water. The Limit of Quantification (LOQ) was established as $0.03 \mathrm{mg} / \mathrm{L}$ from 10:1 peak to noise height ratio. Statistical parameters for recovery $(0.03 \mathrm{mg} / \mathrm{L})$. Table 2 presents the mean percentage of recovery, standard deviation (SD), percentage of relative standard deviation (percent RSD) and Horwitz Limit. The formula for calculation residue and statistical parameters are presented below the equitation.

Residue content $(\mu \mathrm{g} / \mathrm{mL})$

(Eq. 1)

Where $A$ is the peak area of active content in the sample $\left(\mu \mathrm{V}^{*} \mathrm{sec}\right) ; \mathrm{C}$ is the concentration of 
the standard solution $(\mu \mathrm{g} / \mathrm{mL})$; and $\mathrm{D}$ is the peak area of active content in standard solution $(\mu \mathrm{V} * \mathrm{sec})$.

Recovery $\%=\frac{\text { Recovered residue } \times 100}{\text { Fortified concentration }} \quad$ (Eq. 2)
$\%$ RSD $=\frac{\text { Standard deviation } \times 100}{\text { Mean }}$

Where $\mathrm{C}$ is the concentration

\section{Adsorption study of the catalyst}

The amount of catalyst required for the decontamination was optimized as $100 \mathrm{mg} / \mathrm{L}$ for diclosulam, any further increase of catalyst had no significant effect on degradation. The adsorption of catalyst study was conducted by quantifying the concentration of diclosulam in water for three hours.

The recovery was 93 to $96 \%, 91$ to $94 \%, 90$ to $92 \%$ in acidic water, neutral water and basic water respectively. The results indicate no significant loss of residues due to adsorption. In the presence of the catalyst though, the dissipation was found rapid under sunlight.

\section{Photolytic and photocatalytic study}

The photolytic degradation results of diclosulam in water showed the residues are highly stable, the stability decreased with decreasing $\mathrm{pH}$. The results were shown in Table 3 and Fig. 9. Comparatively lower values of diclosulam in the presence of a catalyst (Photocatalytic) in different $\mathrm{pH}$ were recorded. The results were shown in Table 4 and Fig. 10.

The data demonstrate that the decontamination of diclosulam follows pseudo-first-order kinetics in $\mathrm{Cu}-\mathrm{ZnO}$ loaded water. DT50 values were calculated using the following formula: (Eq. 5).

Where ' $\mathrm{k}$ ' is the slope of the curve obtained from the dissipation data.

For photolytic and photo catalytic studies, the calculated DT50 values are shown in Table 5 and Table 6. The constant value of the rate was calculated from the first-order rate equation by the linear regression equation. (Eq. 6)

Where $\mathrm{dt}$ is the time interval between $\mathrm{t} 1$ and $\mathrm{t} 2$ and $\mathrm{a}, \mathrm{x}$ is at times $\mathrm{t} 1$ and $\mathrm{t} 2$ respectively the concentration of diclosulam. A plot of residue and rate concentration with $\mathrm{R} 2$ shows first-order kinetics in diclosulam dissipation. Diclosulam DT50 was calculated from the dissipation data by regression analysis.

The decontamination was fast when studied under sunlight in presence of $\mathrm{Cu}-\mathrm{ZnO}$. Due to the formation of electrons (e-) and positive hole $\left(\mathrm{h}^{+}\right)$in $\mathrm{Cu}-\mathrm{ZnO}$ by absorbing energy from sunlight and the availability of electrons $\left(\mathrm{e}^{-}\right)$and the positive holes $\left(\mathrm{h}^{+}\right)$pairs contributing the simultaneous oxidation and reduction of diclosulam enhances the rate.

In conclusions the different water samples, the $\mathrm{Cu}-\mathrm{ZnO}$ NPs were found to be an excellent decontaminating catalyst for diclosulam. In the absence of a catalyst, the compound persists for several days. Good separation and resolution were shown in the mobile phase, Acetonitrile and HPLC water, and the analysis time required for the chromatographic determination of three different types of buffers is very short (about 15 minutes for a chromatographic run).. Photo catalytic studies of diclosulam at various conditions such as acidic, basic and neutral reveals that the activity is enormously increased with $\mathrm{Cu}-\mathrm{ZnO} \mathrm{NPs}$ as the time frame 
is fixed for a stipulated number of hours, whereas activity did not found without added $\mathrm{Cu}-\mathrm{ZnO} \mathrm{NPs}$, even though experiments were carried out in several days.

\section{References}

Chaudhry, G. R.; Cortez, L. Degradation of Diclosulam by a Pseudomonas Sp. Appl. Environ. Microbiol.1988, 54 (9), 2203-2207. https://doi.org/10.1128/ aem.54.9.2203-2207.1988.

Deepa, L.; Desai, B. K.; Latha, H. S. Research Article Biotoxic Effect of Diclosulam $84 \%$ Wdg On Growth, Nodulation And Nitrogen Content Of Greengram. 2017, 9 (32), 4468-4470.

De Souza, C. da C. B.; Borella, J.; Leal, J. F. L.; Tornisielo, V. L.; Pimpinato, R. F.; Monquero, P. A.; de Pinho, C. F. Limited Diclosulam Herbicide Uptake and Translocation-Induced Tolerance in Crotalaria Juncea. Bull. Environ. Contam. Toxicol. 2020, 104 (1), 114 120. https://doi.org/10.1007/s00128019-02742-7.

Donato, F. F.; Martins, M. L.; Munaretto, J. S.; Prestes, O. D.; Adaime, M. B.; Zanella, R. Development of a Multiresidue Method for Pesticide Analysis in Drinking Water by Solid Phase Extraction and Determination by Gas and Liquid Chromatography with Triple Quadrupole Tandem Mass Spectrometry. J. Braz. Chem. Soc.2015, $26 \quad$ (10), 2077-2087. https://doi.org/10.5935/01035053.20150192.

Jakhar, R. R.; Sharma, R.; Singh, S. B. Evaluation of Diclosulam Residues in Soil at Harvest of Soybean. Int. J. Curr. Microbiol. Appl. Sci. 2017, 6 (2), 1459-1463.

https://doi.org/10.20546/ijcmas.2017.6 02.163.

Kumaravel S, P. R. A Reversed-Phase High-
Performance Liquid Chromatography (RP-HPLC) Determination of Pesticide Residues in Tender Coconut Water (Elaneer/Nariyal Pani). J. Chromatogr. Sep. Tech.2013, 04 (10), 4-6. https://doi.org/10.4172/21577064.1000208.

Pareja, L.; Cesio, V.; Heinzen, H.; FernándezAlba, A. R. Evaluation of Various QuEChERS Based Methods for the Analysis of Herbicides and Other Commonly Used Pesticides in Polished Rice by LC-MS/MS. Talanta 2011, 83 (5), 1613-1622. https://doi.org/10. 1016/j.talanta.2010.11.052.

QUEIROZ, S. C. N.; LAZOU, K.; SANDRA, P.; JARDIM, I. C. S. F. Determination of Pesticides in Water By Liquid Chromatography-(Electrospray Ionization)-Mass Spectrometry (LcEsi-Ms). Pestic. Rev. Ecotoxicologia e Meio Ambient.2004, 14, 53-60. https://doi.org/10.5380/pes.v14i0.3123.

Rajput, S.; Kumari, A.; Arora, S.; Kaur, R. Multi-Residue Pesticides Analysis in Water Samples Using Reverse Phase High-Performance Liquid Chromatography (RP-HPLC). MethodsX2018, 5, 744-751. https://doi.org/10.1016/j.mex.2018.07.0 05.

S, N.; N, R.; K, A. Comparative Evaluation of Extraction Procedures and Chromatographic Techniques for Analysis of Multiresidue Pesticides in Honey. J. Environ. Toxicol. Stud.2017, 1 (1), 1-8. https://doi.org/ 10.16966/2576-6430.102.

Singh, S. P.; Singh, V. P.; Nainwal, R. C.; Tripathi, N.; Kumar, A. Efficacy of Diclosulam on Weeds and Yield of Soybean. 2009, 41, 170-173.

Velkoska-Markovska, L.; PetanovskaIlievska, B.; Markovski, A. Application of High-Performance Liquid Chromatography to the Analysis of 
Pesticide Residues in Apple Juice. Contemp. Agric.2018, 67 (1), 93-102. https://doi.org/10.2478/contagri-20180014.

Williams, R. M.; Kulick, A. R.; Yedlapalli, S.; Battistella, L.; Hajiran, C. J.; Sooter,
L. J. In Vitro Selection of a SingleStranded Dna Molecular Recognition Element Specific for Diclosulam. $J$. Nucleic Acids2014, 2014, 1-9. https://doi.org/10.1155/2014/102968.

\section{How to cite this article:}

Varada Nageswara Rao, N. V. S. Venu Gopal and Patrudu, T. B. 2020. Removal of Diclosulam Pesticide Residues in Water samples using $\mathrm{Cu}$ Doped $\mathrm{ZnO}$ Nanocatalyst Int.J.Curr.Microbiol.App.Sci. 9(11): 910-921. doi: https://doi.org/10.20546/ijcmas.2020.911.109 